\title{
Herpetofauna Diversity at Munggu Village, Landak Regency, West Kalimantan Province, Indonesia
}

\author{
ANDRI MAULIDI ${ }^{1 *}$, MOHAMAD JAKARIA $^{2}$, NURUL FITRIYANA $^{2}$, MUHAMMAD RIZKI $^{1}$ \\ ${ }^{1}$ Department of Biology, Faculty of Mathematics and Natural Science, Palangka Raya University \\ Jl. Yos Sudarso Palangka Raya, Central Kalimantan, Indonesia. 73112 \\ *Email: andrimaulidi@mipa.upr.ac.id \\ ${ }^{2}$ Department of Biology, Faculty of Mathematics and Natural Science, Tanjungpura University \\ Jl. Prof. Dr. H. Hadari Nawawi, Pontianak, West Kalimantan, Indonesia. 78124
}

Received 18 August 2019; Received in revised form 03 October 2019;

Accepted 01 December 2019; Available online 30 December 2019

\begin{abstract}
A large number of forests at Munggu Village, Ngabang District, Landak Regency have been converted into oil palm and rubber plantations. As consequences, natural habitats in the region have been fragmented and species diversity, including herpetofauna, has been decreased. This study aimed to assess herpetofauna diversity in four different habitats in Munggu Village: (1) forests, (2) Landak river, (3) tourist areas, and (4) rubber plantations. Data collection used Visual Encounter Survey (VES) for 8 days. The results showed that the total of 24 herpetofauna species: 15 amphibians' species (4 families) and 9 reptiles species (6 families) have been recorded from the four sampled areas. Of the four locations 11 species were found in river habitat in the forest, 4 species in the location of Landak river, 8 species in tourism sites and 9 species in rubber plantations. The Shannon-Wiener $\left(\mathrm{H}^{\prime}\right)$ diversity index in all four habitats was classified as moderate. In the river location in the forest, $\mathrm{H}^{\prime}$ was 2.14 , in the Landak river it was 1.28 , in the tourism sites it was 1.71 and in the rubber plantation it was 1.87 . However, the evenness index (E) for the herpetofauna community in all four locations was $>0.80$. Habitat loss and habitat destruction are among the causes of decline in amphibian and reptile populations. Knowing the diversity of herpetofauna, it is hoped that the community and stakeholders can collaborate to secure the herpetofauna in Munggu Village.
\end{abstract}

Keywords: amphibians; diversity; plantations; reptiles; West Kalimantan

\section{INTRODUCTION}

Munggu Village, Ngabang District, Landak Regency, West Kalimantan Province is a village located in a hilly area with an altitude of about $700 \mathrm{~m}$ above sea level. Most of the areas of Munggu Village are oil palm, rubber, and forest plantations, which are used as illegal mining areas. This has caused a part of the forest near the village to be converted, even though the land is included in the watershed conservation area that has been protected by local government laws. The variety of land cover types allows for the potential diversity of herpetofauna, and moreover the area around the village still has many rivers and waterfalls. Meanwhile, conversion of forest to agriculture will also have serious consequences for the survival of the organisms inside. The results showed that habitat loss and habitat destruction are one of the main causes of the decline in amphibian (Stuart et al., 2004; Rowley et al., 2009) and reptile populations (Gibbons et al.,
Information regarding the diversity of herpetofauna in Munggu Village has never been reported. Herpetofauna consists of two large groups of vertebrates, namely amphibians and reptiles. Amphibians and reptiles have an important role in the food chain both as predators and prey (Najera-Hillman et al., 2009; Cortés-Gomez et al., 2015; Hopkins et $a l ., 2005)$. The lack of information regarding the diversity of animals in this region has caused less effective management of this area. Gillespie et al. (2005) state that conservation policies and sustainable environmental management can be derived from biodiversityrelated knowledge. Accordingly, this study aimed to analyze the diversity of amphibians and reptiles in various habitat types in Munggu Village, Landak District, West Kalimantan Province. The results of this study are expected to provide input for a better regional management. 2000). 


\section{MATERIALS AND METHODS}

Study sites. The study was conducted at Munggu Village, Ngabang District, Landak Regency, West Kalimantan Province, Indonesia, that were divided into four localities based on their habitat types (1) rubber plantations; (2) forest; (3) Landak river; and (4) tourism sites of the Riam Setegong. Landak River has fast flowed with sand and rocks (large, medium and small) as substrate. Tourism sites have cliffs that are observed along the river bank and there are waterfalls in certain places. Rubber trees (Hevea brasiliensis) dominate in rubber plantations. In the forest has a fairly swift and varied river flow, such as the type of pond, slow flow (riffle), heavy flow (flowing). Vegetation around streams includes ferns, grass, bamboo
(Dendrocalamus asper) and Durian (Durio zibetinus).

Specimen collection. Water quality was measured using $\mathrm{pH}$ meter, thermometer. The camera was used to photograph the specimens. The materials used were plastic bags for storing specimens, tissue, cotton, masks while the chemicals used for making wet preservatives for specimens were $96 \%$ ethanol, $4 \%$ formaldehyde, deionized water, and chloroform.

Data collection in all four locations used the Visual Encounter Survey (VES) method with time constrained search (Heyer et al., 1994; Kusrini, 2019). Retrieving data from each sampling location was carried out twice during the day (08.00-11.00 WIB) to find diurnal herpetofauna and at night (19.00-22.00 WIB) to obtain nocturnal herpetofauna.
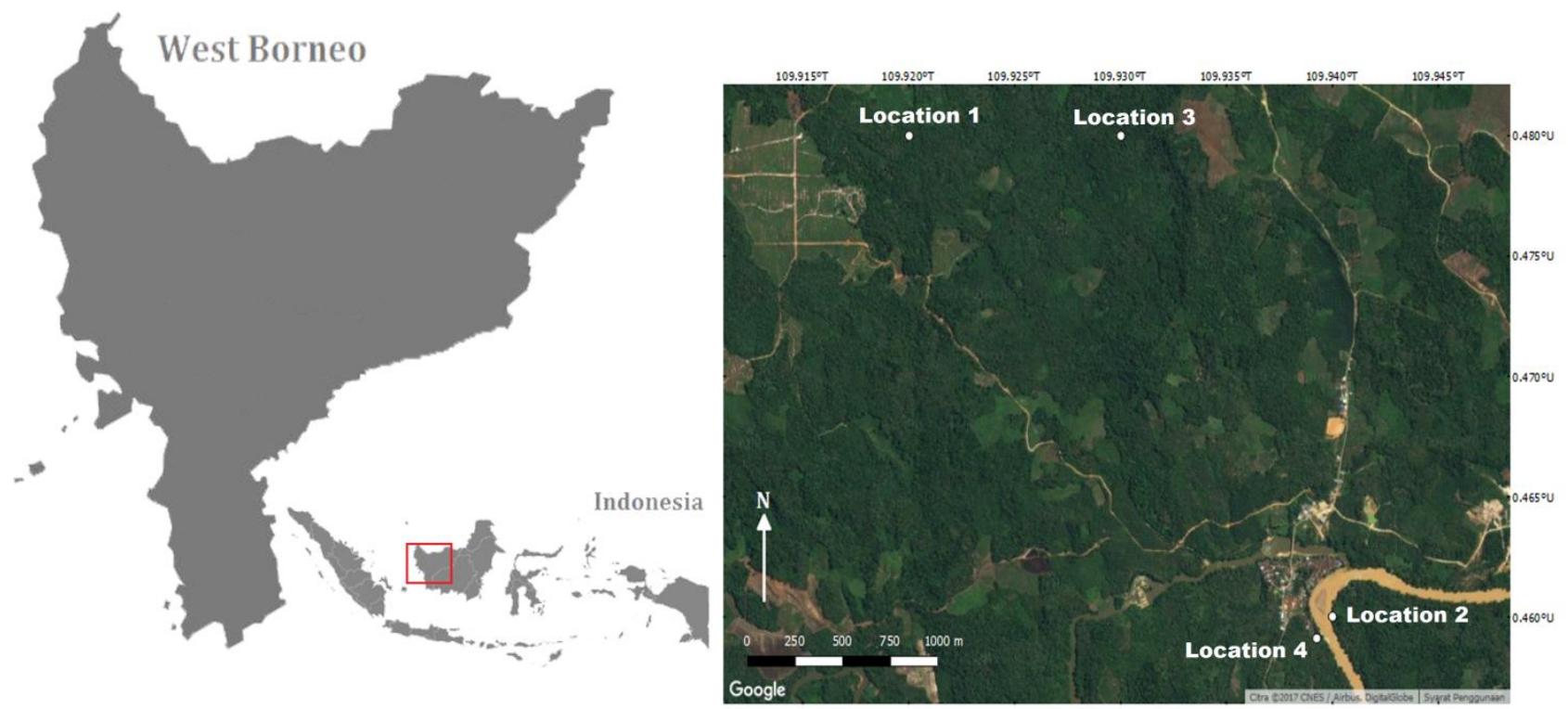

Figure 1. Location sampling in Munggu Village. Location 1: river in the forest, Location 2: Landak river, Location 3 : tourism site, Location 4: rubber plantations.

Species identification. Herpetofauna found were identified using identification keys in the following works: Malkmus et al., (2002), Inger \& Stuebing (2005), Iskandar (1998), and Das (2010).

Abiotic factors measurement. Abiotic factors measured in this study were water temperature, water $\mathrm{pH}$ and humidity. Temperature, water $\mathrm{pH}$, and humidity has an important role in amphibians life. Amphibians body temperatures follow the ambient temperature because amphibians and reptiles are ectotherm-poikilotherm animals (Kusrini, 2019). pH below 4-5 can cause the embryo and amphibian tadpole to die (Kusrini, 2019). Humidity on the frog's skin must be maintained because it also functions as a respiratory tool (Kusrini, 2019).

Data analysis. The data obtained were analyzed using a species diversity index based on Shannon-Wiener Index (H') (Krebs, 1998) with criteria Brower et al. (1998). To determine the degree of evenness at the study site, the Evenness Index (E) was calculated (Henderson 
\& Southwood, 2016). Determination of the level of similarity between the two communities was analyzed based on the Sorensen Index (Riyanto \& Trilaksono, 2012).

\section{RESULT AND DISCUSSION}

We have recorded the total of 24 herpetofauna species consisting of 15 amphibian species and 9 reptile species during survey for 8 days at Manggu village (Table 1). Among 15 amphibian species, four of them (Staurois guttatus, Limnonectes leporinus, Leptobrachium abbotti and Ansonia spinulifer) were endemic species to Borneo. Additionally, we recorded Amyda cartilaginea among 9 reptile species that is listed as Vulnerable (VU) species of IUCN.

Table 1 shows that the location with the highest number of species was the River in the forest, with herpetofauna of 11 species, followed by the rubber plantations (nine species), tourism sites (eight species), and lastly, the Landak river (four species). The low number of species found at the Landak river due to the river location has reduced water quality, turbidity caused by gold mining, which discharges waste and mercury directly into the river basin which results in river pollution. Dry soil conditions and forest floors are dominated by dry litter, only certain species can live in areas like this. Besides that, the river flow is swift, so that not all species can live in the habitat. Species found in Landak river locations were Odorana hossi, Leptobrachium abbotti, Phrynoidis aspera, and Eutropis multifasciata. In contrast to the location of the Landak river, the river water in the forest has not experienced human disturbances and has a fairly dense vegetation with a lush forest canopy, making this location an ideal living place for many types of herpetofauna.

The number of herpetofauna species found in Munggu Village was quite high when compared to the herpetofauna found in the coalmine reclamation land of PT. Singlurus Pratama, East Kalimantan, where only 21 species were found (Muslim et al., 2016). However, the herpetofauna species in the West Kalimantan Munggu Village was lower when compared to the Lesan River Protected Area in East Kalimantan, with 31 species (Tajalli et al., 2011), and West Kalimantan Betung Kerihun National Park, with 51 species (BKNP, 2012). The large number of species found was due to the broad scope of studies in these two locations and includes a variety of habitat types.

Table 1. List of herpetofauna from four locations in Munggu Village recorded in this study

\begin{tabular}{|c|c|c|c|c|c|c|c|}
\hline \multirow[b]{2}{*}{ Family } & \multirow[b]{2}{*}{ Spesies } & \multicolumn{6}{|c|}{ Research Sites } \\
\hline & & $\begin{array}{l}\text { IUCN } \\
\text { Status }\end{array}$ & $\begin{array}{l}\text { River } \\
\text { in the } \\
\text { Forest }\end{array}$ & $\begin{array}{c}\text { Landak } \\
\text { River }\end{array}$ & $\begin{array}{l}\text { Tourism } \\
\text { Sites }\end{array}$ & $\begin{array}{c}\text { Rubber } \\
\text { Plantations }\end{array}$ & Total \\
\hline \multirow[t]{8}{*}{ Ranidae } & Amnirana nicobariensis & $\mathrm{LC}$ & 3 & & & 2 & 5 \\
\hline & Odorrana hossi & $\mathrm{LC}$ & 4 & 1 & 10 & & 15 \\
\hline & Pulchrana signata & $\mathrm{LC}$ & 1 & & 1 & & 2 \\
\hline & Chalcorana raniceps & $\mathrm{LC}$ & 1 & & & & 1 \\
\hline & Hylarana erythraea & $\mathrm{LC}$ & & & & 7 & 7 \\
\hline & Pulchrana picturata & $\mathrm{LC}$ & & & 2 & & 2 \\
\hline & Pulchrana baramica & $\mathrm{LC}$ & & & 2 & 3 & 5 \\
\hline & Staurois guttatus* & $\mathrm{LC}$ & 8 & & 3 & & 11 \\
\hline \multirow[t]{3}{*}{ Dicroglossidae } & Limnonectes kuhlii & $\mathrm{LC}$ & 4 & & 1 & & 5 \\
\hline & Limnonectes leporinus* & $\mathrm{LC}$ & 3 & & & & 3 \\
\hline & Limnonectes sp. & $\mathrm{LC}$ & & & & 1 & 1 \\
\hline Megophryidae & Leptobrachium abbotti* & $\mathrm{LC}$ & & 2 & & & 2 \\
\hline \multirow[t]{3}{*}{ Bufonidae } & Ansonia spinulifer* & $\mathrm{LC}$ & 5 & & & & 5 \\
\hline & $\begin{array}{l}\text { Ingerophrynus } \\
\text { quadriporcatus }\end{array}$ & $\mathrm{LC}$ & & & & 1 & 1 \\
\hline & Phrynoidis aspera & $\mathrm{LC}$ & & 3 & & 1 & 4 \\
\hline \multirow[t]{3}{*}{ Scincidae } & Eutropis rudis & - & & & & 1 & 1 \\
\hline & Eutropis multifasciata & $\mathrm{LC}$ & & 1 & & & 1 \\
\hline & Tropidophorus beccarii & LC & 1 & & & & 1 \\
\hline
\end{tabular}




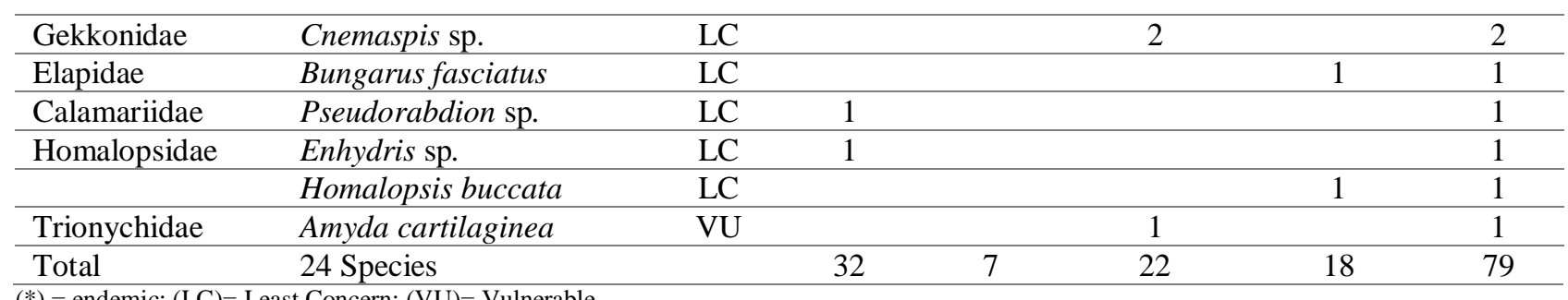

Total amphibians found in this study were 79 individuals from 15 species. Ranidae was the family with the highest number of individuals (48), while Megophryidae was the smallest family, namely one species of Leptobrachium abbotti. The species with the highest number were Odorana hossi, with as many as 15 individuals, while the smallest numbers were found in Ingerophrynus quadriporcatus, Chalcorana raniceps, and Limnonectes sp., with only one discovered individual. Among the reptiles, the highest number of individuals was shown by Cnemaspis sp. (Gekkonidae), with two individuals. However, when compared to the amphibians, fewer reptiles were found. This was due to the reptiles being more difficult to find and identify because they has a more active movement compared to the amphibian class.

Diversity can be seen from the diversity index $\left(\mathrm{H}^{\prime}\right)$ and evenness index $(\mathrm{E})$. The herpetofauna diversity in several habitat types in Munggu Village can be seen in Table 2. Based on the results of the study the diversity index in four locations was classified as moderate $\left(1<\mathrm{H}^{\prime}<3\right)$, with a diversity index value of 2.14 in river in the forest locations, 1.28 in Landak river locations, 1.71 in Tourism sites, and 1.87 in rubber plantations.

Table 2. Diversity Index and Evenness of the Herpetofauna

\begin{tabular}{clccc}
\hline No & Locations Name & $\begin{array}{c}\text { Total of } \\
\text { Individuals }\end{array}$ & Diversity Index (H') & Evenness Index (E) \\
\hline 1 & River in the Forest & 32 & 2.14 & 0.89 \\
\hline 2 & Landak River & 7 & 1.28 & 0.92 \\
\hline 3 & Tourism Sites & 22 & 1.71 & 0.82 \\
\hline 4 & Rubber Plantations & 18 & 1.87 & 0.85 \\
\hline
\end{tabular}

Rivers in the forest had the highest diversity value, due to the greater number of species (11) and the distribution of the 32 individuals found in this location. The lowest diversity index value found in the location of Landak river was 1.28 , because the number of species found at this location was only four herpetofauna species with seven individuals.

The differences in the level of diversity can be influenced by several factors, including temperature and humidity, which are very important environmental factors for herpetofauna, which, as ectothermic animals, regulate their body temperature through the surrounding environment (Laurencio \& Fitzgerald, 2010; Sasaki et al., 2005). Body heat is obtained from the environment, thus the environment greatly affects the lives of reptiles. Reptiles usually expose their bodies to the sun with the aim of increasing their body temperature and getting the desired body heat from sunlight for metabolic processes. In areas exposed to sunlight, reptiles are often found sunbathing in the morning to reach the required body temperature (Christian et al., 2006; Zwart, 2001; Rocha et al., 2002). Some types of reptiles were found during the day as Eutropis rudis. Amphibians tend to be found more at night, only a few species could be found during the day, such as Staurois guttatus and Ingerophrynus quadriporcatus, while almost all other species were found at night.

Nocturnal types of herpetofauna are more common than diurnal ones. Nocturnal herpetofauna types include Amninara nicobariensis, Odorana hossi, Pulchrana signata, Chalchorana raniceps, Hylarana erythraea, Pulchrana picturata, Pulchrana 
baramica, Limnonectes kuhlii, Limnonectes leporinus, Limnonectes sp., Leptobrachium abbotti, Ansonia spinulifer, Phrynoidis aspera, Eutropis multifasciata, Tropidophorus beccarii, Bungarus fasciatus, Homalopsis buccata, Enhydris sp. and Amyda cartilaginea. While diurnal types include Staurois gutatus, Ingerophrynus quadriporcatus, Cnemaspis sp. and Psudorabadion sp. This showed that the pattern of herpetofauna space use is influenced by its activity. Amphibians tend to be active at night to avoid the risk of predation, while there are several types of reptiles that can be found during the day (Eprilurahman et al., 2009; Vignoli \& Luiselli, 2013; Leaché et al., 2006; Vermunt et al., 2014). Factors that cause the differences in herpetofauna activity are influenced by environmental factors such as temperature, because temperature has a high influence herpetofauna life due to the body temperature that fluctuates with the temperature of the environment (poikilotherm-ectotherm). Thus, the behavior, movements and different activity patterns show the way an organism responds to environmental influences.

Table 3. Results of Abiotic Factor Measurement at the Four Locations

\begin{tabular}{ccccccccc}
\hline Locations & \multicolumn{2}{c}{ Rivers in the Forest } & \multicolumn{2}{c}{ Landak River } & \multicolumn{2}{c}{ Tourism Sites } & \multicolumn{2}{c}{ Rubber Plantations } \\
\cline { 2 - 9 } Condition & Day & Night & Day & Night & Day & Night & Day & Night \\
\hline Water & $26^{\circ} \mathrm{C}$ & $26^{\circ} \mathrm{C}$ & $30^{\circ} \mathrm{C}$ & $25^{\circ} \mathrm{C}$ & $28^{\circ} \mathrm{C}$ & $24^{\circ} \mathrm{C}$ & $27^{\circ} \mathrm{C}$ & $26^{\circ} \mathrm{C}$ \\
Temperature & $40 \%$ & $50 \%$ & $40 \%$ & $54 \%$ & $20 \%$ & $61 \%$ & $58 \%$ & $58 \%$ \\
Humidity & $40 \%$ & 6.8 & 5 & 5 & 6 & 6 & 5 & 5 \\
Water pH & 6.8 & 6.8 &
\end{tabular}

The results of water temperature measurements carried out during the study ranged from $24-30^{\circ} \mathrm{C}$, while the results of the measurement of water $\mathrm{pH}$ showed that the aquatic environment at the research site in acidic conditions in the range of 5-6.8 (Table 3 ), which was in accordance with the characteristics of acidic Kalimantan soils, because it was dominated by peatlands.

The evenness index value (E) can describe the stability of a community, if the evenness value $(\mathrm{E})$ is close to 1 , then it shows the distribution of individuals among species is similar. But if it is much less than 1 , there is a high probability of a dominant species existence in the community. The evenness index value of species $(\mathrm{E})$ in each location has its own variation, the lowest value was found in the tourism sites was 0.82 and rubber plantations was 0.85 , the river in the forest of 0.89, while the highest in the Landak river location was 0.92 . According to the results, the herpetofauna found in this study had different abundances. Most can only be found in one location as Amyda cartilaginea, found only in clean river areas. For Serpentes members such as Homalopsis buccata, Bungarus fasciatus,
Pseudorabdion sp., and Enhydris sp. were represented by a small number of individuals, one individual each. The abundant types of herpetofauna were easily found in each study location such as Odorana hossi, Pulchrana signata, Pulchrana baramica, Ansonia spinulifer. The abundance of Odorana hossi at each study location shows that the species had a high tolerance level for disturbed environmental conditions.

Sorensen Index (Community similarities and habitat utilization). The similarity of herpetofauna communities in the four locations analyzed using the Sorensen index revealed a low level of community similarity between the four locations (Table 4). The location of the river in the forest and the Landak River had a similarity of $13.33 \%$, the river in the forest and the Tourism Sites at $42.11 \%$, the river in the forest and the Rubber Plantation at $10 \%$. Similarity between the location of the Landak River and the Tourism Sites is $16.67 \%$, and between Landak River and the Rubber Plantation $15.38 \%$. The location of tourism sites and rubber plantations had a similarity level of $11.76 \%$. 
Table 4. Sorensen Index

\begin{tabular}{lcccc}
\hline \multicolumn{1}{c}{ Locations } & $\begin{array}{c}\text { Rivers in the Forest } \\
(\boldsymbol{\%})\end{array}$ & $\begin{array}{c}\text { Landak Rivers } \\
(\boldsymbol{\%})\end{array}$ & $\begin{array}{c}\text { Tourism Sites } \\
(\boldsymbol{\%})\end{array}$ & $\begin{array}{c}\text { Rubber } \\
\text { Plantations }(\boldsymbol{\%})\end{array}$ \\
\hline Rivers in the Forest & - & - & - & - \\
Landak River & 13.33 & - & - & - \\
Tourism Sites & 42.11 & 16.67 & - & - \\
Rubber Plantations & 10.00 & 15.38 & 11.76 & - \\
\hline
\end{tabular}

The location of the River in the Forest and the Tourism Sites had a greater degree of similarity because in both locations the same number of species was found more than in other locations. Comparing the river location in the forest and the tourism sites, only four of the same species were found in the two locations, while comparing the rubber plantation location and the river in the forest, the lowest value was found because only 1 species found in the two locations. One type of reptiles found in this study has IUCN status in the vulnerable category (VU: Vulnerable), namely: Amyda cartilaginea due to a decline in population caused by capture in nature, trade for consumption and pets (Riswanto \& Hedianto, 2016). While other types included in the category have not received attention (LC: Least Concern).

\section{CONCLUSION}

Through this study, we have recorded 10 individuals of 9 reptile species (6 families) and 15 species of amphibians (10 genera, 4 families). Amyda cartilaginea, a species listed as vulnerable (IUCN) and four endemic species of Bornean amphibian/reptiles (Staurois guttatus, Limnonectes leporinus, Leptobrachium abbotti, Ansonia spinulifer) were observed during the study. Among the four localities, the highest level of herpetofaunal diversity was observed in the forest $\left(H^{\prime}: 2.14\right)$ and the Landak river had the lowest diversity (H': 1.28). On the other hand, the Landak river had highest level of equality (evenness index of 0.92) and the tourism site had equality being the lowest (evenness index of 0.82). By knowing the diversity of herpetofauna, it is hoped that the community and stakeholders can collaborate with each other in to secure the herpetofauna in Munggu Village.

\section{ACKNOWLEDGMENTS}

We thank Muhammad Ali Hamzah from Landak Regency, who served as guide and assisted in specimen collection in Munggu Village.

\section{REFERENCES}

Betung Kerihun National Park. 2012. Management Plant Betung Kerihun National Park, West Kalimantan 20002024. Executive Summary. Kapuas Hulu: Betung Kerihun National Park. p. 5.

Brower JE, Zar JH, von Ende C. 1998. Field and laboratory methods for general ecology. New York: WCB McGraw-Hill. p 250.

Christian KA, Tracy CR, Tracy CR. 2006. Evaluating thermoregulation in reptiles: an appropriate null model. The American Naturalist. vol 168(3): 421-430. doi: https://doi.org/10.1086/506528.

Cortés-Gomez AM, Ruiz-Agudelo CA, Valencia-Aguilar A, Ladle RJ. 2015. Ecological functions of neotropical amphibians and reptiles: a review. Universitas Scientiarum. vol 20(2): 229245.

http://dx.doi.org/10.11144/Javeriana.SC20 -2.efna.

Das I. 2016. A Field Guide to The Reptiles of South-East Asia. London: Bloomsbury Natural History. p. 370.

Eprilurahman R, Himly MF, Qurniawan TF. 2009. Studi Keanekaragamasn Reptil dan Amfibi di Kawasan Ekowisata Linggo Asri, Pekalongan, Provinsi Jawa Tengah. Berkala Penelitian Hayati. vol 15(1): 9397. doi: https://doi.org/10.23869/bphjbr.15.1.2009 15.

Gibbons JW, Scott DE, Ryan TJ, Buhlmann KA, Tuberville TD, Metts BS, Greene JL, 
Mills T, Leiden Y, Poppy S, Winne CT. 2000. The Global Decline of Reptiles, Déjà $\mathrm{Vu}$ Amphibians: Reptile species are declining on a global scale. Six significant threats to reptile populations are habitat loss and degradation, introduced invasive species, environmental pollution, disease, unsustainable use, and global climate change. BioScience. vol 50(8): 653-666. doi: $\quad$ https://doi.org/10.1641/00063568(2000)050[0653:TGDORD]2.0.CO;2

Gillespie G, Howard S, Lockie D, Scroggie M. 2005. Herpetofaunal Richness and Community Structure of Offshore Islands of Sulawesi, Indonesia 1. Biotropica: The Journal of Biology and Conservation. vol 37(2): 279-290. doi: https://doi.org/10.1111/j.17447429.2005.00038.x.

Henderson PA, and Southwood TR. 2016. Ecological methods. $4^{\text {th }}$ ed. New Jersey: Wiley-Blackwell. pp. 7-60.

Heyer WR, Donnelly MA, McDiarmid RW, Hayek LAC, Foster MS. 1994. Measuring and Monitoring Biological Diversity: Standard Methods for Amphibians. Washington: Smithsonian Books. p. 384.

Hopkins WA, Staub BP, Baionno JA, Jackson BP, Talent LG. 2005. Transfer of selenium from prey to predators in a simulated terrestrial food chain. Environmental Pollution. vol 134(3): 447-456. doi: https://doi.org/10.1016/j.envpol.2004.09.0 10.

Inger RF, Stuebing RB, Grafe TU, Dehling JM. 2017. A Field Guide to the Frogs of Borneo. 3rd ed. Kinabalu: Natural History Publications Borneo. p.219.

Iskandar DT. 1998. The amphibians of Java and Bali. Bogor: Research and Development Centre for Biology LIPI. p.110.

Krebs CJ. 1998. Ecological Methodology. $2^{\text {nd }}$ ed. San Francisco: Benjamin Cummings. p.520.

Kusrini MD. 2019. Metode survei dan penelitian herpetofauna. Bogor: IPB Press. p. 150

Laurencio D, and Fitzgerald LA. 2010. Environmental correlates of herpetofaunal diversity in Costa Rica. Journal of Tropical Ecology. vol 26(5): 521-531. doi: https://doi.org/10.1017/S02664674100002 22.

Leaché AD, Rödel MO, Linkem CW, Diaz RE, Hillers A, Fujita MK. 2006. Biodiversity in a forest island: reptiles and amphibians of the West African Togo Hills. Amphibian and Reptile Conservation. vol 4(1): 22-45. doi:

https://doi.org/10.1514/journal.arc.004001 8.

Malkmus R, Manthey U, Vogel G, Hoffmann P, Kosuch J. 2002. Amphibians and reptiles of mount Kinabalu (North Borneo). London: Serpent's Tale NHBD. pp. 400-424.

Muslim T, Sari UK, Widyawati. 2016. Keanekaragaman herpetofauna di lahan reklamasi tambang batubara PT Singlurus Pratama Kalimantan Timur. Prosiding Seminar Nasional Biologi. 6 Juni 2016. Makassar: Jurusan Biologi, Universitas Hasanuddin. ISBN 978-602-72198-3-0. pp. 63-67.

Najera-Hillman E, Alfaro AC, Breen BB, O'Shea S. 2009. Characterisation $(\delta 13 \mathrm{C}$ and $\delta 15 \mathrm{~N}$ isotopes) of the food webs in a New Zealand stream in the Waitakere Ranges, with emphasis on the trophic level of the endemic frog Leiopelma hochstetteri. New Zealand Journal of Zoology. vol 36(2): 165-176. doi: https://doi.org/10.1080/030142209095101 49.

Riswanto, and Hedianto DM. 2016. Status pemanfaatan dan perlindungan labi-labi (Amyda cartilaginea) di Provinsi Kalimantan Timur. Prosiding Forum Nasional Pemulihan dan Konservasi Sumber Daya Ikan V. 20 Oktober 2015. Purwakarta: Balai Penelitian Pemulihan dan Konservasi Sumberdaya Ikan. ISBN 978-602-19535-4-9. pp. 323-330.

Riyanto A, and Trilaksono W. 2012. Komunitas herpetofauna di lereng timur Gunung Slamet, Jawa Tengah. In Ekologi Gunung Slamet: geologi, klimatologi, biodiversitas dan dinamika sosial. Bogor: LIPI Press. pp. 151-160. 
https://doi.org/10.5072/RIN/UIATPJ.

Rocha CFD, Dutra GF, Vrcibradic D, Menezes

VA. 2002. The terrestrial reptile fauna of the Abrolhos Archipelago: species list and ecological aspects. Brazilian Journal of Biology. vol 62(2): 285-291. doi: http://dx.doi.org/10.1590/S151969842002000200013.

Rowley J, Brown R, Bain R, Kusrini M, Inger R, Stuart B, Wogan G, Thy N, Chan-ard T, Trung CT, Diesmos A, Iskandar DT, Lau M, Ming LT, Makchai S, Truong NQ, Phimmachak S. 2009. Impending conservation crisis for Southeast Asian amphibians. Biology letters. vol 6(3): 336338.

doi: https://doi.org/10.1098/rsbl.2009.0793.

Sasaki K, Palmer MW, Hayashi T. 2005. Influence of climate, elevation, and land use in regional herpetofaunal distribution in Tochigi Prefecture, Japan. Community Ecology. vol 6(2): 219-227. doi: https://doi.org/10.1556/ComEc.6.2005.2.1 0 .

Stuart SN, Chanson JS, Cox NA, Young BE, Rodrigues ASL, Fischman DL, Waller RW. 2004. Status and trends of amphibian declines and extinctions worldwide. Science. vol 306(5702): 1783-1786. doi: https://doi.org/10.1126/science.1103538.

Tajalli A, Kusrini MD, Kartono AP. 2011. Keanekaragaman Jenis Reptil Di Kawasan Lindung Sungai Lesan, Kalimantan Timur. [Skripsi]. Bogor: Institut Pertanian Bogor.

Vignoli L, and Luiselli L. 2013. Better in the dark: two Mediterranean amphibians synchronize reproduction with moonlit nights. Web Ecology. vol 13(1): 1-11. doi: https://doi.org/10.5194/we-13-1-2013.

Vermunt A, Hare KM, Besson AA. 2014. Unusual change in activity pattern at cool temperature in a reptile (Sphenodon punctatus). Journal of Thermal Biology. vol 42: 40-45. doi: https://doi.org/10.1016/j.jtherbio.2014.02. 021.

Zwart P. 2001. Pathophysiology: Assessment of the husbandry problems of reptiles on the basis of pathophysiological findings: A review. Veterinary Quarterly. vol 23(4): 140-147. doi: https://doi.org/10.1080/01652176.2001.96 95103. 